\title{
REVIEWS
}

\section{GLYCOALKALOIDS IN POTATOES: A REVIEW}

\author{
Reinis Zarins*, Zanda Kruma \\ Department of Food Technology, Faculty of Food Technology, Latvia University of Agriculture, Rigas iela 22, Jelgava, Latvia, \\ e-mail: reinis-zarins@inbox.lv
}

\begin{abstract}
Potatoes (Solanum tuberosum L.) are one of the most consumed and nutritionally important vegetables in the world, which is why its quality and safety are very important. Potential risk factors for potato consumers are some toxins called glycoalkaloids, which naturally accumulates in potatoes during growth, harvesting, transportation and storage. It is stated that safe glycoalkaloid concentration level into fresh potato tubers with skin is not higher than $200 \mathrm{mg} \mathrm{kg}^{-1}$. Figures above this concentration might affect the health of consumers, causing, for example, digestive troubles and nerve system damage. The objective of this review is to outline the glycoalkaloid classification, the factors affecting the glycoalkaloid accumulation process, and the effect on technological processes of the glycoalkaloid level in potato tubers. The goal of this review is to highlight the importance of this subject and to encourage the widening of the glycoalkaloid research horizon. Different research shows that the most significant glycoalkaloid concentration raise happens during potato tuber exposure to direct sunlight. If for a few hours under direct sunlight, the glycoalkaloid concentration rises considerably. Prolonged potato storage under bulb light, for example, on shop counters, also raises the glycoalkaloid concentration. Peeling significantly reduces glycoalkaloid concentration, because glycoalkaloids are partly removed from potato tubers with the skin. Also, boiling potatoes in water and also the frying process remove partly the glycoalkaloids. Cutting, slicing, rinsing with water, baking, cooking, blanching, pulsed electric field do not significantly affect the glycoalkaloid concentration in potatoes tubers.
\end{abstract}

Keywords: potatoes, glycoalkaloids, solanine, chaconine, technological processes.

\section{Introduction}

Potatoes are important vegetables and are widely grown and consumed due to the fact that they yield good crops under different growing conditions, while containing many valuable nutritional compounds, such as proteins, carbohydrates, vitamins, minerals (Lisińska et al., 2009; Rytel et al., 2011). Potatoes yield also has more calories per acre than other widely grown crops (Navarre et al., 2009).

Apart from nutritional compounds, potatoes also contain glycoalkaloids, viz. naturally accumulated toxins during potato growth and storage. Glycoalkaloid accumulation is triggered by environmental (natural and human stimulated) stress (Papathanasiou et al., 1999; Sharma, Salunkhe, 1989). Major glycoalkaloids in potatoes are $\alpha$-solanine and $\alpha$-chaconine (Sotelo, Serrano, 2000; Friedman, Levin, 2009; Omayio et al., 2016). As stated by the World Health Organization, the safe level of glycoalkaloids in fresh potato tubers is considered to be from 20 to $100 \mathrm{mg} \mathrm{kg}^{-1}$ (Food and Agriculture Organization / World Health Organization, Joint Expert Committee on Food Additives, 1992). However, other studies state that even up to $200 \mathrm{mg}$ of glycoalkaloids $\mathrm{kg}^{-1}$ of fresh potatoes is still safe (Jansky, 2010; Friedman et al., 1997; Karim et al., 1997). Glycoalkaloid intoxication might cause digestive troubles, diarrhoea and vomiting (Hellenas et al., 1992), but higher doses can cause nerve system damage, coma and even death (Friedman, 2006; Langkildea et al., 2009).

The bitter taste of potatoes is one of the indicators of increased glycoalkaloid level presence and is common in potatoes (fresh weight) which have more than $140 \mathrm{mg}$ per $\mathrm{kg}$ of glycoalkaloids (Sinden et al., 1976; Zitnak, Filadelfi, 1985; Johns, Keen, 1986).

Some in vitro studies show certain beneficial effects of glycoalkaloids, for example, anticancer effect
(Friedman et al., 2005; Lee et al., 2004), but this possibly positive value of glycoalkaloids still need to be well studied and admission of glycoalkaloids for medical purposes cannot be done directly from fresh or processed potatoes.

It is important to avoid potatoes exposure to direct sunlight during harvesting and storage, as this can drastically and fast raise the glycoalkaloid level, forcing its concentration above the maximum safe limit (Kirui et al., 2009).

In the storage process, for example, in shop counters usually potatoes are affected by two negative factors, i.e., too high (room) temperature and bulb light; after prolonged influence of those factors, potatoes start to sprout and/or turn green, while also accumulating glycoalkaloids (Cantwell, 1996).

Basically any light source can increase the glycoalkaloid level during storage and even during potatoes growth, when some potatoes are not properly covered with soil (Dimenstein et al., 1997).

Slicing, bruising and cutting are human-stimulated stress factors which also raise the glycoalkaloids level (Mondy et al., 1987; Mondy, Gosselin, 1988).

Potatoes are quite different genetically in their ability to produce glycoalkaloids (Dale et al., 1993), which is why it would be advisable to find and use potatoes varieties which have lower glycoalkaloid accumulation tendency.

Some technological processes might help to reduce the glycoalkaloid level. It is important to understand the conditions in which glycoalkaloid level raises, so as to try to avoid such conditions, while it is vital to ascertain technological processes that reduce the glycoalkaloid level.

A great deal of research has been made worldwide on glycoalkaloids. The aim of this article is to summarize the key points on glycoalkaloid classification, accumulation and reduction. The objective of this 
review is to outline the classification of glycoalkaloids, the factors affecting the glycoalkaloid accumulation process, and the effect of technological processes on glycoalkaloid level in potatoes tubers.

\section{Materials and Methods}

In this review, a monographic method has been used, i.e., studying scientific papers on the classification of glycoalkaloids, the factors affecting the glycoalkaloid accumulation process, and the technological process effect on glycoalkaloid level.

\section{Results and Discussion}

\section{Chemical structure of glycoalkaloids}

Glycoalkaloids are secondary metabolites and the most common alkaloids within the Solanaceae family. These compounds are biosynthesised from cholesterol - the same precursors as steroids. In Solanum species, the main glycoalkaloids are solanidanes and spirosolanes. In potatoes, two most important glycoalkaloids are $\alpha$-solanine and $\alpha$-chaconine (Figure 1), consisting of solanidine as an aglycone, but bound with different sugar moieties (Chowanski et al., 2016; Wang et al., 2013). Generally, glycoalkaloids $\alpha$-solanine and $\alpha$-chaconine are present in plants together, especially in S.tuberosum (Vaananen, 2007).

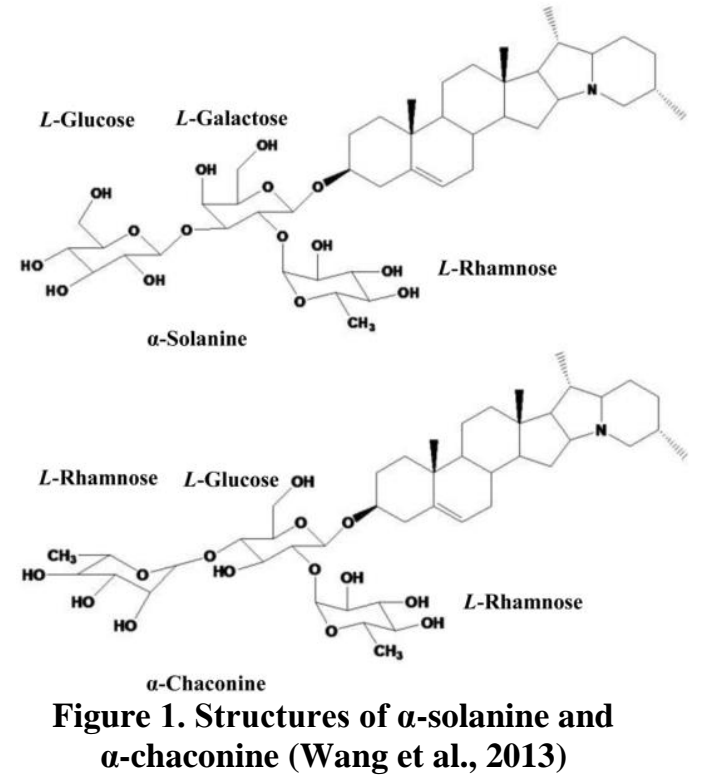

The trisaccharide sugar moieties of $\alpha$-solanine is called a solatriose, consisting of D-glucose, D-galactose, L-rhamnose, whereas $\alpha$-chaconine is called a chacotriose, consisting of D-glucose and two L-rhamnose molecules (Vaananen, 2007). Other glycoalkaloids ( $\beta$-solanine, $\gamma$-solanine, $\beta$-chaconine, $\gamma$-chaconine, $\quad \alpha$-solamarine, $\quad \beta$-solamarine, 5 - $\beta$-solanidan-3-aol and demissidine) are in very low concentrations (Friedman, McDonald, 1997). $\alpha$-chaconine is more toxic than $\alpha$-solanine and in several studies the ratio between $\alpha$-solanine and $\alpha$ chaconine is compared.
Biological activity of glycoalkaloids

Glycoalkaloids are present in potatoes and many other members of Solanaceae, including eggplants and tomatoes, and they are secondary metabolites, whose main role is to protect potatoes from environmental stress, for example, pathogens and injuries (Navarre et al., 2009). The biological activity of alkaloids for protecting plants comes in a broad range: redox imbalance, disruption of biological membranes, disturbed metabolism, inhibition of cholinesterase, reproductive toxicity, disturbed development, etc. (Chowanski et al., 2016).

Based on insecticidal activities, different studies are performed for glycoalkaloids application as sources of new insecticides (Chowanski et al., 2016; Nenaah, 2011). There are many glycoalkaloid poisoning cases, but it is hard to identify all of them, as such poisoning symptoms are similar to bacterial food poisoning (Smith et al., 1996; Mensinga et al., 2005).

\section{Content of glycoalkaloids in potatoes}

No maximum levels for glycoalkaloids in potatoes have been established at EU level. Some Member States have a national maximum level of $200 \mathrm{mg}$ per $\mathrm{kg}^{1}$. Glycoalkaloids are located in the whole potatoes plant, but the highest concentration is in unripe fruit, sprouts, flowers and potato tuber skin (Friedman, 2005).

The glycoalkaloid content of potato tubers depends on the potato cultivar and ranges from $22.4 \mathrm{mg}$ to $208.9 \mathrm{mg}$ per $\mathrm{kg}$ of fresh potato tubers (Friedman, McDonald, 1999).

In Latvia, grown potatoes total glycoalkaloid level ranges from $12.9 \mathrm{mg}$ to $28 \mathrm{mg}$ per $\mathrm{kg}$ fresh potato weight (whole potato with skin) and from 1.9 to $21.5 \mathrm{mg}$ per $\mathrm{kg}$ fresh potato weight (potato without skin) (Saleniece et al., 2011).

Examples of distribution of glycoalkaloids in white, yellow, red and blue flesh potatoes are presented in Table 1 .

Table 1

Glycoalkaloids in white, yellow, red and blue flesh potatoes (Rytel et al., 2013; Friedman, 2005)

\begin{tabular}{lc}
\hline \multicolumn{1}{c}{ Sample } & $\begin{array}{c}\text { Total glycoalkaloids mg kg-1 } \\
\text { fresh weight }\end{array}$ \\
\hline White-flesh potatoes & Whole tuber \\
Blue-flesh potatoes & approx. up to 629 \\
Red-flesh potatoes & $54-59$ \\
Yellow-flesh potatoes & $51-55$ \\
& Peels \\
White-flesh potatoes & approx. up to 100 \\
Blue-flesh potatoes & approx. up to 3526 \\
Red-flesh potatoes & $181-245$ \\
Yellow-flesh potatoes & approx. up to 1264 \\
\hline
\end{tabular}

The glycoalkaloid level can depend on specific potatoes genetics and geographical factors (Friedman, 2006). The level can raise during harvesting

\footnotetext{
1 https://ec.europa.eu/food/sites/food/files/safety/docs/reg-com_toxic _20150623_sum.pdf
} 
process, transportation and storage and it is provoked by tuber damage, exposure to pathogens, direct light from sun or bulb, heat (Friedman, 2006; Kirui at al., 2009). If prolonged exposure to direct sunlight is avoided during harvesting, then such exposure might take place when potato tubers are sold in fairs, as in such cases tubers are temporarily stored in uncovered counters whole day under clear sky and there is a high risk of buying high glycoalkaloid level affected potato tubers (Kirui et al., 2009).

To present the ideological distribution of glycoalkaloids in different potato parts, there is an example below, in Table 2. These data were established in the $20^{\text {th }}$ century and are still valid under specific research conditions and are provided here to generally show the significant difference of glycoalkaloids in different potato parts.

Table 2

Glycoalkaloids in potatoes (Wood, Young, 1974)

\begin{tabular}{ll}
\hline \multicolumn{1}{c}{ Potato part } & \multicolumn{1}{c}{$\begin{array}{c}\text { Total glycoalkaloids, } \\
\text { mg per kg fresh weight }\end{array}$} \\
\hline Tuber with skin & 75 \\
Tuber with skin (bitter taste) & $250-800$ \\
Peel (skin) & $150-600$ \\
Peel (skin) from bitter tuber & $1500-2200$ \\
Tuber without skin & $12-50$ \\
Sprouts & $2000-4000$ \\
Flowers & $3000-5000$ \\
Stems & 30 \\
Leaves & $400-1000$ \\
\hline
\end{tabular}

Glycoalkaloids accumulate twice as fast at $24{ }^{\circ} \mathrm{C}$ than $7{ }^{\circ} \mathrm{C}$ in dark room, but in light they can develop even up to nine times faster already after 24 hours at $24{ }^{\circ} \mathrm{C}$ when also exposed to bulb light (Cantwell, 1996).

Table 3 shows examples of glycoalkaloid accumulation amount in different light and temperature conditions. Direct sunlight, brighter artificial light, less glycoalkaloid accumulation resistant potato varieties and the simultaneous influence of several negative conditions (i.e., direct light plus high temperature) might result in faster glycoalkaloid accumulation.
Table 3

Glycoalkaloid accumulation in different light and temperature conditions in whole tuber

(Machado, 2007)

\begin{tabular}{|c|c|c|}
\hline Condition & Days & $\begin{array}{c}\text { Total glycoalkaloids, mg } \\
\text { per kg fresh weight }\end{array}$ \\
\hline $\begin{array}{ll}\text { Indirect } & \text { sunlight } \\
\text { exposure } & \end{array}$ & $0 / 3$ & $51.4 / 96.9$ \\
\hline $\begin{array}{l}\text { Fluorescent light } \\
\text { exposure (lamps of } \\
40 \mathrm{~W} \text { ) }\end{array}$ & $0 / 3$ & $51.4 / 59.9$ \\
\hline $\begin{array}{l}\text { Storage in darkness } \\
\text { under refrigeration } \\
\text { temperature } \\
\left(7-8^{\circ} \mathrm{C}\right)\end{array}$ & $0 / 3$ & $51.4 / 75$ \\
\hline $\begin{array}{l}\text { Storage in } \\
\text { darkness under } \\
\text { room temperature } \\
\left(19-26^{\circ} \mathrm{C}\right)\end{array}$ & $0 / 3$ & $51.4 / 76.5$ \\
\hline
\end{tabular}

Influence of technological processes to glycoalkaloids content

The influence on glycoalkaloids of the technological processes carried out on potatoes are presented in Table 4. Depending on the glycoalkaloid overall content in specific cases, potato tubers peeling can reduce the glycoalkaloid level up to $58 \%$ (Czopek et al., 2008; Czopek et al., 2012).

Cutting, slicing and rinsing with water barely reduces the level of glycoalkaloids. Blanching potatoes has a slightly higher effect compared to the previously mentioned processes and removes a small part of glycoalkaloids, because, since they are water soluble, a part of them is removed during this process; however, the removed amount is insignificant (Rytel et al., 2005; Peksa et al., 2006).

Boiling in water reduces glycoalkaloids in whole potato tubers by $22 \%$ in average, due to the glycoalkaloid solubility in water, hence some part of glycoalkaloids leak from tubers in that process (Czopek et al., 2008). Comparing frying, baking and cooking, only frying reduces glycoalkaloids due to high working temperature (Friedman, McDonald, 1997; Rytel et al., 2005; Peksa et al., 2006).

Influence of technological processes to glycoalkaloids

Table 4

\begin{tabular}{lll}
\hline Process & \multicolumn{1}{c}{$\begin{array}{c}\text { Reduction of total } \\
\text { glycoalkaloids }\end{array}$} & \multicolumn{1}{c}{ Reference } \\
\hline Frying & approx. up to 94\% & Peksa et al., 2006; Czopek et al., 2012; Rytel et al., 2011 \\
Blanching & Insignificant effect & Rytel et al., 2005; Peksa et al., 2006 \\
Dehydration & $78-90 \%$ & Rytel et al., 2013 \\
Boiling & $22 \%$ & Czopek et al., 2008 \\
Potato chips & approx. up to 82\% & Czopek et al., 2012 \\
Peeling & approx. up to 58\% & Czopek et al., 2008; Czopek et al., 2012 \\
Granulation & approx. up to 90\% & Ji et al., 2012 \\
Cutting, slicing, rinsing & No effect & Rytel et al., 2005; Peksa et al., 2006 \\
with water & & \\
Baking, cooking & Insignificant effect & Friedman, McDonald, 1997; Rytel et al., 2005; Peksa et al., 2006 \\
Pulsed electric field & Insignificant effect & Hossain et al., 2015 \\
\hline
\end{tabular}


Other study shows similar result when the frying temperature was higher than $170{ }^{\circ} \mathrm{C}$ (Friedman, McDonald, 1997). However, some studies present even better results, decreasing total glycoalkaloids by up to 94\% during the frying process (Czopek et al., 2012).

Pulsed electric field does not significantly reduce glycoalkaloid level in potatoes tubers after treatment (Hossain et al., 2015).

\section{Conclusions}

Generally, the glycoalkaloid level in potato tubers depends on genetics, environmental and physical stresses.

Damage during harvesting, transportation or storage raises glycoalkaloid level.

Prolonged storage of potatoes should be done at temperature of $7^{\circ} \mathrm{C}$, since higher temperature can stimulate accumulation of glycoalkaloids level.

Room temperature plus bulb light in potato tubers particularly raises glycoalkaloid level.

Direct sunlight gives fastest glycoalkaloid accumulation in potato tubers, while direct bulb light influence to tubers takes a bit longer time for glycoalkaloids to accumulate.

Significant glycoalkaloid level reduction can be achieved by peeling, sliced tubers boiling in water or frying, dehydration and granulation.

Insignificant glycoalkaloid level reduction results from cutting, slicing, rinsing with water, baking, cooking and pulsed electric field.

Bitter taste, sprouts and green skin of potatoes are indicators which consumers can observe, to avoid intoxication with glycoalkaloids.

\section{References}

1. Cantwell M. (1996) A Review of Important Facts about Potato Glycoalkaloids. Perishables Handling Newsletter, Vol. 87, p. 26-27.

2. Chowanski S., Adamski Z., Marciniak P., Rosinski G., Buyukguzel E., Buyukguzel K., Falabella P., Scrano L., Ventrella E., Lelario F., Bufo S.A. (2016) A Review of Bioinsecticidal Activity of Solanaceae Alkaloids. Toxins, Vol. 8(3), p. 1-28.

3. Czopek A.T., Szyszka M.J., Lisinska G. (2008) Changes in glycoalkaloids content of potatoes destined for consumption. Food Chemistry, Vol. 106(2), p. 706-711.

4. Czopek T.A, Szyszka J.M, Lisinska G. (2008) Changes in glycolalkaloids content of potatoes destined for consumption. Food Chemistry, Vol. 106(2), p. 706-711.

5. Czopek T.A., Rytel E., Kita A., Peksa A., Hamouz K. (2012) The influence of thermal process of coloured potatoes on the content of glycoalkaloids in the potato products. Food Chemistry, Vol. 133(4), p. $1117-1122$.

6. Dale M.F.B., Grfiffiths D. W., Bain H., Todd D. (1993) Glycoalkaloid increase in Solanum tuberosum on exposure to light. Annals of Applied Biology, Vol. 123, p. 411-418.

7. Dimenstein L., Lisker N., Kedar N., Levy D. (1997) Changes in the content of steroidal glycoalkaloids in potato tubers grown in the field and in the greenhouse under different conditions of light, temperature and day length. Physiological and Molecular Plant Pathology, Vol. 50, 391-402.

8. Food and Agriculture Organization/World Health Organization, Joint Expert Committee on Food Additives. (1992) Evaluation of Certain Food Additives and naturally Occurring Toxicants. In: 39th report of the Joint FAO/WHO Expert Committee on Food Additives; WHO Technical Report Series 828, Switzerland, Geneva, p. 31-33.

9. Friedman M. (2003) Chemistry, biochemistry and safety of acrylamide. Journal of Agricultural and Food Chemistry, Vol. 51(4), p. 504-4526.

10. Friedman M. (2005) Analysis of biologically active compounds in potatoes (Solanum tuberosum L.), tomatoes (Lycopersicon esculentum L.), and jimson weed (Datura stramonium L.) seeds. Journal of Chromatography, Vol. 1054, p. 143-155.

11. Friedman M. (2006) Potato glycoalkaloids and metabolites: roles in the plant and in the diet. Journal of Agricultural and Food Chemistry, Vol. 54, p. 8655-8681.

12. Friedman M., Lee K.R., Kim H.J., Lee I.S., Kozukue N. (2005) Anticarcinogenic effects of glycoalkaloids from potatoes against human cervical, liver, lymphoma, and stomach cancer cells. Journal of Agricultural and Food Chemistry, Vol. 53, p. 6162-6169.

13. Friedman M., Levin C.E. (2009) Analysis and biological activities of potato glycoalkaloids, calystegine alkaloids, phenolic compounds and anthocyanins. In: Advances in Potato Chemistry and Technology. Singh J., Kaur L. (eds). UK: Academic Press, p. 127-161.

14. Friedman M., McDonald G.M. (1999) Postharvest changes in glycoalkaloid content of potatoes. Advances in Experimental Medicine and Biology, Vol. 459, p. 121-143.

15. Friedman M., McDonald G.M., Keszi M.F. (1997) Potato glycoalkaloids: chemistry, analysis, safety and plant physiology. Critical Reviews in Plant Sciences, Vol. 16(1), p. 55-132.

16. Hellenas K.E., Nyman A., Slanina P., Loof L., Gabrielsson J. (1992) Determination of Potato Glycoalkaloids and Their Aglycone in Blood Serum by High-Performance Liquid Chromatography: Application to Pharmacokinetic Studies in Humans. Journal of Chromatography Biomedical Applications, Vol. 573, p. 69-78.

17. Hossain M.B., Aguayo I.A., Lyng J.G., Brunton N.P., Rai D.K. (2015) Effect of pulsed electric field and pulsed light pre-treatment on the extraction of steroidal alkaloids from potato peels. Innovative Food Science and Emerging Technologies, Vol. 29, p. 9-14.

18. Jansky S.H. (2010) Potato flavor. American Journal of Potato Research, Vol. 87(2), p. 209-217.

19. Ji X., Rivers L., Zielinski Z., Xu M., MacDougall E., Stephen J., Zhang S., Wang Y., Chapman R.G., Keddy P., Robertson G.S., Kirby C.W., Embleton J., Worrall K., Murphy A., Koeyer D., Tai H., Yu L., Charter E., Zhang J. (2012) Quantitative analysis of phenolic components and glycoalkaloids from 20 potato clones and in vitro evaluation of antioxidant, cholesterol uptake, and neuroprotective activities. Food Chemistry, Vol. 133, p. $1177-1187$.

20. Johns T., Keen S.L. (1986) Taste evaluation of potato glycoalkaloids by the Ayamara: a case study in human chemical ecology. Human Ecology, Vol. 14(4), p. 437-452.

21. Karim M.S., Percival G.C., Dixon G.R. (1997) Comparative composition of aerial and subterranean 
potato tubers (Solanum tuberosum L). Journal of the Science of Food and Agriculture, Vol. 75, p. 251-257.

22. Kirui K.G., Misra A.K., Olanya O.M., El-Bedewy R., Ewell P.T., Friedman M. (2009) Glycoalkaloid content of some superior potato (Solanum tuberosum L.) clones and commercial cultivars. Archives of Phytopathology and Plant Protection, Vol. 42, p. 453-463.

23. Langkildea S., Mandimika T., Schrøder M., Meyer O., Slob W., Peijnenburg A., Poulsen M. (2009) A 28-day repeat dose toxicity study of steroidal glycoalkaloids, $\alpha$-solanine and $\alpha$-chaconine in the Syrian Golden hamster. Food Chemistry and Toxicology, Vol. 47, p. $1089-1098$.

24. Lee K.R., Kozukue N., Han J.S., Park J.H., Chang E.Y., Baek E.J., Chang J.S., Friedman M. (2004) Glycoalkaloids and metabolites inhibit the growth of human colon (HT29) and liver (HepG2) cancer cells. Journal of Agricultural and Food Chemistry, Vol. 52, p. 2832-2839.

25. Lisińska G., Pęksa A., Kita A., Rytel E., Czopek T.A. (2009) The quality of potato for processing and consumption. In: Potato IV. Vol. 2. Food. Yee N., Bussel W. (eds). UK: Global Science Books, p. 99-104.

26. Machado R.M.D., Toledo M.C.F., Garcia L.C. (2007) Effect of light and temperature on the formation of glycoalkaloids in potato tubers. Food Control, Vol. 18, p. 503-508.

27. Mensinga T.T., Adrienne J.A.M.S., Rompelberg C.J.M., Twillert K., Meulenbelt J, Top H.J., Egmond H.P. (2005) Potato glycoalkaloids and adverse effects in humans: an ascending dose study. Regulatory Toxicology and Pharmacology, Vol. 41, p. 66-72.

28. Mondy N.I., Gosselin B. (1988) Effect of peeling on total phenols, total glycoalkaloids, discoloration and flavor of cooked potatoes. Journal of Food Science, Vol. 53, p. 756-759.

29. Mondy N.I., Leja M., Gosselin B. (1987) Changes in total phenolic, total glycoalkaloid, and ascorbic acid content of potatoes as a result of bruising. Journal of Food Science, Vol. 52, p. 631-635.

30. Navarre D.A, Goyer A., Shakya R. (2009) Nutritional Value of Potatoes: Vitamin, Phytonutrient and Mineral Content. Advances in potato chemistry and technology, Vol. 14, p. 395-424.

31. Nenaah G.E. (2011) Toxic and antifeedant activities of potato glycoalkaloids against Trogoderma granarium (Coleoptera: Dermestidae). Journal of Stored Products Research, Vol. 47, p. 185-190.

32. Omayio D.G., Abong G.O., Okoth M.W. (2016) A Review of occurrence of glycoalkaloids in potato and potato products. Current Research in Nutrition and Food Science, Vol. 4(3), p. 195-202.

33. Papathanasiou F., Mitchell S.H., Watson S., Harvey B.M.R. (1999) Effect of environmental stress during tuber development on accumulation of glycoalkaloids in potato (Solanum tuberosum L.).
Journal of the Science of Food and Agriculture, Vol. 79, p. 1183-1189.

34. Peksa A., Golubowska G., Aniolowski K., Lisinska G., Rytel E. (2006) Changes of glycoalkoaloids and nitrate contents in potatoes during chips processing. Food Chemistry, Vol. 97, p. 151-156.

35. Rytel E., Czopek A.T., Aniolowska M., Hamouz K. (2013) The influence of dehydrated potatoes processing on the glycoalkaloids content in coloured-fleshed potato. Food Chemistry, Vol. 141, p. 2495-2500.

36. Rytel E., Golubowska G., Lisinska G., Peksa A., Aniolowski K. (2005) Changes in glycoalkaloid and nitrate contents in potatoes during French fries processing. Journal of the Science of Food and Agriculture, Vol. 85, p. 879-882.

37. Rytel E., Pęksa A., Czopek A.T., Kita A., Lisińska G. (2011) Anti-nutritional compounds in potatoes, depending on the type of raw material and conditions of processing potatoes into food products. In: Potato $V$. Vol. 1. Food. Yee N., Bussel W. (Eds). UK: Global Science Books, p. 15-22.

38. Saleniece K., Nakurte I., Kḷaviņš K., Kirhnere I., Mekšs P., Skrabule I., Muceniece R. (2011) Content of glycoalkaloids $\alpha$ solanine and $\alpha$ chakonine in potatoes grown in Latvia. Latvijas Universitātes raksti, Vol. 773, p. 46-55.

39. Sharma R.P., Salunkhe D.K. (1989) Solanum glycoalkaloids. In: Toxicants of Plant Origin, Vol. 1. Alkaloids. Cheeke P.R. (ed). USA: CRC Press, p. 179-236.

40. Sinden S.L., Deahl K.L., Aulenbach B.B. (1976) Effect of glycoalkaloids and phenolics on potato flavor. Journal of Food Science, Vol. 41(3), p. 520-523.

41. Smith D.B., Roddick J.G., Jones J.L. (1996) Potato Glycoalkaloids: Some Unanswered Questions. Trends in Food Science and Technology; Vol. 7, p. 126-131.

42. Sotelo A., Serrano B. (2000) High-performance liquid chromatographic determination of the glycoalkaloids alpha-solanine and alpha-chaconine in 12 commercial varieties of Mexican potato. Journal of Agricultural and Food Chemistry, Vol. 48, p. 2472-2475.

43. Vaananen T. (2007) Glycoalkaloid Content and Starch Structure in Solanum Species and Interspecific Somatic Potato Hybrids. Ph.D. thesis. University of Helsinki, Helsinki, p. 1-79.

44. Wang H., Liu M., Hu X., Li M., Xiong X. (2013) Electrochemical determination of glycoalkaloids using a carbon nanotubes-phenylboronic acid modified glassy carbon electrode. Sensors, Vol. 13, p. 16234-16244.

45. Wood F.A., Young D.A. (1974) TGA in potatoes. Canada Department of Agriculture, Vol. 1533, p. 1-3.

46. Zitnak A., Filadelfi M.A. (1985) Estimation of taste thresholds of three potato glycoalkaloids. Canadian Institute of Food Science and Technology Journal, Vol. 18(4), p. 337-339. 